\title{
Pedagogy in Operations Research: Where has the discipline been, where is it now, and where should it go?
}

\author{
James J Cochran* \\ Received: 24 August 2009; Revised: 6 October 2009; Accepted: 23 October 2009
}

\begin{abstract}
This paper provides a review of the history of operations research pedagogy and the progress the discipline has made in improving the quality of education it provides college students since its recognized inception during World War II. Recent and current trends are examined and ongoing activities and initiatives in operations research pedagogy are discussed. Finally, implications for the future of operations research are considered.
\end{abstract}

Key words: Education, pedagogy, operations research, management science, instruction, history.

\section{Introduction}

While operations research pedagogy was relatively static for several decades in the early life of the discipline, the landscape has changed rapidly and dramatically over the past two decades. As the discipline of operations research advances, it is instructive to ask what changes in pedagogy have occurred and why have they occurred. Perhaps even more important is the question of whether the trends represented by these changes can be extrapolated to provide insight into how operations research pedagogy will (or should) continue to evolve. These are the primary questions to be addressed in this paper.

The author begins with a few qualifying statements to give the reader an understanding of his background and perspective. He finished his undergraduate education in 1982, and received his Master of Science degree in Economics and MBA in 1984 (all at Wright State University in Dayton, Ohio). He began teaching introductory operations research/management science courses for undergraduate business majors and MBA students at Wright State University in 1984. After teaching for three years as a full-time instructor (teaching four sections and three course preparations per academic term), the author left academia for private industry. He returned to academia in 1993 and earned his $\mathrm{PhD}$ in Statistics and Operations Research from the University of Cincinnati in 1997. He has since

* Department of Marketing and Analysis, College of Business, PO Box 10318, Louisiana Tech University, Ruston, LA 71272, United States of America, email: jcochran@cab.latech.edu 
taught introductory and graduate level operations research and statistics courses at the University of Cincinnati, Miami University, and Louisiana Tech University. Courses the author has taught include statistical methods, operations research methods, mathematical programming, regression analysis, categorical data analysis, mathematical probability and statistics, design and analysis of experiments, and survival analysis. In teaching the introductory survey course in operations research, the author has used textbooks written by Cook and Russell (1981), Eppen et al. (1987), Anderson et al. (1994), Ragsdale (1998), Lapin (1994), and Lapin and Whisler (2002).

\section{Where has operations research pedagogy been?}

There is a single and unambiguous (albeit somewhat fuzzy) point of demarcation between two distinct eras of operations research pedagogy. Until approximately 1990 introductory operations research courses generally featured a heavy focus on the mathematical underpinnings of solution algorithms for various classes of problems. The author completed his introductory operations research courses as an undergraduate in the early 1980s; the two courses he completed (one course dealing with deterministic methods, the other with stochastic methods) were required coursework for all business and economics undergraduate majors. Topics such as the simplex method, the relationship between the primal and dual formulations, the Hungarian algorithm, modified distribution method (MODI), and the algebra and geometry of parametric sensitivity analysis were prominently featured in both the textbook and lectures, while application-oriented concepts such as model building and the interpretation and implication of results were only briefly considered. Application to various disciplines was demonstrated primarily through example problems in the textbook, and LINDO (on a mainframe computer using some long forgotten model of IBM punch card reader) was the software of choice. A review of popular textbooks from this era confirms that this was the well-established standard approach to introductory operations research courses at that time. For examples of such textbooks, see Churchman et al. (1957), Bierman et al. (1961), Horowitz (1965), Anderson et al. (1976), Buffa and Dyer (1978), Hillier and Lieberman (1980), Lapin (1980), Cook and Russell (1981), and Markland (1983).

As a student, the author had no complaints about this approach; it was well suited to him and his interests, and he is confident most readers of this article had similar experiences. He had not heard of operations research before taking these courses, but was immediately and absolutely captivated by the simplex method; the plethora of interesting and useful information imbedded in each iteration fascinated and amazed him. Sadly (but in retrospect not surprisingly), most of the author's classmates did not share his enthusiasm. They left these classes seeing operations research as a collection of arcane mathematical tools that require massive computing power when applied to real problems and could only be used by highly technical individuals to solve extremely large and complex problems. In short, these students learned only to be intimidated by operations research.

While the author has no empirical evidence to offer, he believes that throughout this period the discipline of operations research, in its collective approach to introductory courses, consistently produced students with attitudes similar to those of his college classmates. 
Many of these students have risen to executive levels, are responsible for decision making for their employers (or in many cases, for the companies they own), and would benefit in many instances from intelligent applications of operations research. Unfortunately the attitude they developed in these introductory operations research courses tenaciously persists, and students from this era generally are blind to the potential benefits of the discipline. The author believes that this explains, to a great extent, why operations research has failed to develop a concrete identity with its potential stakeholders after its initial successful efforts following the discipline's rapid development during World War II (Morse, 1953; Rau, 2000, 2005; Kirby, 2003; Thomas, 2004). For discussions on the difficulties operations research has experienced in attempting to create and strengthen its identity among its potential stakeholders, see Horner (2002, 2003), Müller-Merbach (2004), Balez (2004), and List (2004).

While much of the effort to modernize operations research pedagogy has occurred recently, concern over this issue was expressed at a very early point in the discipline's history (Kendall, 1958). Several colleagues, including Kendall (1958), Webster (1971), Hess (1974a, 1974b), Ackoff (1979a, 1979b, 1987), Eilon (1980), Corbett and Van Wassenhove (1993), Papageorgiou (1996), Bell (1997) and Powell (1998a) presciently warned of the eventual academic backlash against operations research, and in the 1990s the repercussion they warned of began to materialize. As documented by INFORMS Education Committee (1995), the INFORMS Business School Education Task Force (1996), and later by Grossman (2001), businesses were advising colleges that they saw little use for the content of operations research courses. University administrators and faculty colleagues from other disciplines began to question the wisdom of (and the need for) the operations research component of the undergraduate business curriculum. Eventually the American Association of Schools and Colleges of Business (then the AASCB, now the AACSB International) removed operations research from its list of mandated disciplines to be covered in accredited undergraduate business programs (Cook, 2003). Once the AACSB took this action, the frenzy began and operations research requirements were reduced or eliminated completely from programs across the United States (the author's understanding from discussions with colleagues is that to a lesser extent, a similar trend developed in business schools throughout the world). In many schools operations research and statistics were combined into an awkward hybrid course. Operations research was rapidly loosing much of its academic position and identity.

\section{Where is operations research pedagogy now?}

In the early 1990s a paradigm shift in operations research pedagogy slowly began to emerge (perhaps in reaction to the academic backlash discussed in the previous paragraphs). Many instructors, frustrated with traditional approaches to teaching introductory operations research, began developing courses that moved away from coverage of solution algorithms and instead focused squarely on applications. Classroom discussions began to deal more substantively with model building, interpretation of results, and implementation issues. Several operations research instructors contributed to this movement.

Morris (1967) and Woolsey (1984) were very early and staunch proponents of teaching 
modelling skills to students. Geoffrion (1997) provided insight to instructors who wanted to increase the emphasis on modelling in their operations research courses. Gass (1990) discussed the advantages and disadvantages of the end user who also acts as the modeller. Powell (1995a, 1995b, 1997a, 1998b, 2001) and Pidd (1999) have advocated a shift from teaching students to be intelligent consumers of operations research to preparing students to being active modellers and users of the tools the discipline has to offer. Liberatore and Nydick (1999) discussed their efforts to reorient the first management science course in their university's MBA program toward modelling. Olsen (2008) and others have stressed the need for a stronger emphasis on critical thinking.

To make room for these topics, some bolder instructors drastically reduced (or eliminated) coverage of highly technical concepts such as the simplex algorithm. Again, evidence of the strength of this movement can be found inside the front covers of several modern introductory operations research textbooks; a cursory review of the tables of contents reveals that many of these texts relegate coverage of the simplex method and other solution algorithms to appendices, and some provide absolutely no coverage of many of these topics. The authors of several well-established textbooks, such as Anderson et al. (2006), have revised their approach and placed much greater emphasis on modelling and applications. Additionally, several of the introductory operations research textbooks that have been published in the past fifteen years have a similar orientation and emphasis (for examples, see Ragsdale (1998) and Powell and Baker (2008)).

Of course, one does not see unanimity in approaches to undergraduate operations research courses, nor should one expect or want to see conformity to a single pedagogical approach. Several instructors continue to successfully use traditional approaches and focus on solution algorithms, while those who have adopted nontraditional approaches have moved in diverse directions. As one reflects on new approaches that have been adopted by these instructors, it is constructive to consider specific ways operations research instructors have changed their approaches and their possible motivations in making these changes.

\subsection{Active learning}

Some instructors may be trying to contend with the notion that learning is a naturally active process and that true understanding of a complex concept is most effectively developed through student interaction with concepts, the instructor, and other students. This can naturally lead an instructor to consider use of active learning pedagogical strategies, strategies that have a long history of success but have been largely dismissed by modern colleges and universities in favor of the more direct lecture approach.

While a quality lecture can be an exceptionally efficient means of transferring information or demonstrating simple concepts, from the student perspective it is a passive activity that generally does not engage her/him in the subject matter (Hartley and Cameron, 1967; McLeish, 1968). Results of a study conducted by Russell et al. (1984) suggest that students learn and retained lecture information better when the density of new material is low, and they propose that no more than half of any class meeting be devoted to the presentation/coverage of new concepts or material. McKeachie (1999) indicated that holding a student audience's attention throughout a long lecture is an extremely difficult task of which few instructors are capable (the author actually finds that few entertainers 
are capable of accomplishing this task, and that is their job!). Consider scientific sessions at conferences or training sessions at work - for how long did the presenter speak before audience members began to feel tired, restless, and perhaps even edgy? Given these experiences, is it not surprising that Hartley and Davies (1978) found that the typical student's level of attention increases during the first ten minutes of a typical lecture and then rapidly diminishes?

Many instructors find resonance in Hartley and Davies' results; they feel that overdependence on lectures creates a stagnant, turgid, and lethargic learning environment in which students are not compelled (or even encouraged) to question and discuss ideas, listen actively, think critically, form opinions, or experiment with concepts. These instructors have been frustrated by watching students walk away from lectures with only a superficial understanding (or less) of concepts and ideas discussed (Russell et al., 1984).

Several research studies (as summarized by Chilcoat (1989)) have found that by changing the classroom environment during a lecture, an instructor can effectively recapture her/his students' attention. Other studies provide evidence that while a simple break from the lecture can certainly accomplish this goal, the break can be far more effective if it features a relevant and effective active learning exercise (Cashin, 1985; Brown and Atkins, 1988; Campbell and Smith, 1995; Cochran, 2001a \& 2001b). Chickering and Gamson (1987) provide an excellent summary of this school of thought:

"Learning is not a spectator sport. Students do not learn much just by sitting in class listening to teachers, memorizing prepackaged assignments, and spitting out answers. They must talk about what they are learning, write about it, relate it to past experiences, apply it to their daily lives. They must make what they learn part of themselves."

In an attempt to combat the intellectual lassitude they believe is induced by overreliance on lectures, many operations research instructors use active learning exercises to give students a break from the lecture and (hopefully) recapture their attention - at least for another ten minutes! In order to understand how these instructors attempt to accomplish this very desirable feat, one must first consider what is meant by the relatively ubiquitous term active learning. Many published definitions exist, but the author prefers a definition (which he has assembled from the portions of these published definitions) that is most in accord with what he believes:

"Instructional strategies and activities designed to engage students through their participation in exercises that involve them in higher-order thinking tasks such as analysis, synthesis, and evaluation of course material."

So why might active learning exercises help students more effectively take ownership of what they learn? Participation in these activities allows students to use their own unique learning styles to deal with concepts on their own terms and work through ambiguities and misconceptions. Students are not forced to learn on their instructor's terms (and the author strongly believes that most students do not learn and understand quantitative 
concepts and reasoning in a manner similar to those with advanced degrees in quantitative sciences).

Active learning can also help an instructor shift the responsibility for learning back to the students and dramatically increase the students' roles in their educations. This, in turn, should improve student comprehension, retention, critical thinking and problem solving skills, and intellectual confidence/self reliance; the author believes the operations research community will agree that these are all goals to which college level instructors of quantitative sciences should aspire.

Of course, instructors who teach introductory quantitative methods courses must also deal with the sense of intimidation many (most?) students feel when faced with quantitative coursework. Instructors understand that operations research is not generally terribly complex or difficult to understand, but the discipline does appear extremely foreign and daunting to the uninitiated. This apprehension about quantitative concepts and coursework exacerbates the problem of holding students' attention.

Why are undergraduate students intimidated by quantitative material? Many are poorly prepared, have little prior knowledge or understanding of quantitative methods, and are anxious about the prerequisite mathematics skills. Fortunately, active learning exercises can also be used to address this problem; student apprehension can be eased if the instructor provides classroom opportunities for students to work with and process quantitative concepts and methods. These opportunities can engender a deeper understanding and appreciation of quantitative material within students, which in turn fortifies the students' self confidence and tolerance for the frustration of studying what they feel to be relatively difficult quantitative concepts, which ultimately leads back to an even deeper understanding and appreciation of quantitative material (Garfield, 1993; Keeler and Steinhorst, 1995; Giraud, 1997; Gnanadesikan et al., 1997; Magel, 1998; Rumsey, 1998). All instructors of operations research (and all members of the operations research community - even those not in academia - are at some level instructors of operations research) should strive for this developmental cycle as the ultimate goal for students - successful learning that supports and encourages the next wave of successful learning!

Leaders in the movement to integrate active learning strategies into introductory operations research courses have written extensively on this topic. ORMS Today (the bimonthly membership magazine of the Institute for Operations Research and the Management Sciences or INFORMS) has published several articles on effective active learning exercises in its "Issues in Education" column. Examples include Liebman (1996), Pendegraft (1997), and Cochran (2001a). In these columns the authors make very convincing cases for the effectiveness of simple but thought-provoking active learning exercises. Their suggestions are also inexpensive, easy to use and extend, and transfer effortlessly across cultures.

Several authors have also published articles on active learning and operations research in INFORMS Transactions on Education. Brimberg and Hurley (2007), Cochran (2001b), Hannibalsson (2001), DePuy and Taylor (2007), Talluri (2009), Taras and Grossman (2003), and Teich et al. (2005), as well as others, have contributed articles that provide details on effective active learning exercises. INFORMS Transactions on Education also published an entire special issue in September 2007 on educational games (Volume 8, Number 1) that was guest edited by Paul Griffin, and the journal features a regular series 
of articles on puzzles and operations research by Martin Chlond.

A great deal of anecdotal evidence on the effectiveness of active learning across cultures has accumulated. For example, after attending workshops at the $1^{\text {st }}$ ALIO/INFORMS Teaching Effectiveness Colloquium in 2006, Funes (2008) began earnestly integrating active learning exercises into her operations research courses at the Instituto de Estadística y Demografía at the Universidad Nacional de Córdoba. She reports great success with active learning and has discussed her work at recent conferences in South America. The results of implementing active learning reported by various operations research instructors suggests the need for a scientific investigation into the characteristics that differentiate courses in which active learning is successful from courses in which active learning does not improve student comprehension and retention.

There is no denying that an instructor must make a substantial investment in order to effectively incorporate active learning exercises into her/his classroom. However, this investment can yield a tremendous potential return for the students, the instructor, and the discipline of operations research. By stimulating a student's interest in operations research through effective active learning exercises, the instructor will develop students who naturally have much stronger understandings of operations research and who will be far more receptive to the enormous potential of operations research.

\subsection{Cases}

Other instructors are concerned with deeper integration of real problems of a manageable size and scope into their operations research courses. The motivation of these instructors may be their frustrations with the ineffectiveness of the traditional lecture as a tool for helping students appreciate the relevance of operations research to their educations and lives. These instructors see the lecture as a constrictive format that only accommodates relatively trivial examples which do not represent meaningful application to authentic problems. They also understand that modern college students are very perceptive goal/career oriented individuals who quickly lose interest in a subject when they do not see its relevance to their ambitions and educational objectives.

These instructors have been further frustrated by students' inability to use basic tools of operations research in an appropriate manner upon completing the introductory operations research course. They have found that students who complete a lecture-only format introductory operations research course frequently show a disappointing inability to recognize when application of various operations research methods are appropriate or inappropriate. This supposition is strongly supported by the frequency with which students give illogical responses (or no responses) when answering exam questions, which suggests these students lack fundamental understanding of some course material. Further support of this hypothesis comes from colleagues in other departments who have found that few students actually apply tools from the introductory operations research coursework to their later coursework. Particularly troubling are the students' lack of understanding of how to formulate all but the most trivial of problems and their failure to properly interpret the results of their analyses. In short, many operations research instructors have been frustrated because their students have not developed basic modelling skills in the introductory business operations research course. 
The initial response of many of these instructors was to attempt to place stronger emphasis on the development of modelling skills in their lectures. However, maintaining the emphasis on solution algorithms established by most colleges and schools of business left an inadequate amount of in-class time to devote to the development of these skills. Thus, many of these instructors greatly reduced or eliminated their emphasis on the algebra of solution algorithms to allow for more extensive efforts to develop their students' modelling skills in the introductory operations research courses.

This change alone would not be sufficient; instructors found that students needed to practice these modelling skills on practical problems that were more complex than homework problems routinely provided by introductory operations research textbooks. Furthermore, the students would see much greater relevance in operations research if they could practice their modelling skills on real problems from other disciplines relevant to their studies (finance, marketing, industrial engineering, etc.).

Ultimately many of these instructors turned to cases as a means of providing their students with this practical experience. While a few instructors (and entire programs) completely abandoned traditional lectures in favour of exclusive reliance on cases, other instructors were more tentative in their integration of cases (Cochran, 2000); they were understandably concerned, because they had already greatly reduced the emphasis on several traditional topics to allow for a greater orientation toward development of modelling skills, and were now faced with the potential loss of additional classroom time to discussions of cases. However, several proceeded with the integration of cases after eventually deciding that fostering student understanding of a few key concepts was more important than providing a broad introductory survey of the discipline. Many (including the author) were very pleasantly surprised to find that cases could be an extremely efficient and effective means of supporting students in the development of their modelling skills, and that this could actually be accomplished without sacrificing the expected topical coverage through a lecture/case hybrid course in which cases and lectures are integrated and mutually supportive (Cochran, 2000).

Several operations research instructors have documented their use of classroom cases. For examples from a variety of perspectives see Bodily (1996); Bell and Von Lanzenauer (2000); Cochran (2000, 2004); Schmedders and Stephens (2001); Cibej (2002); Gavirneni (2006); Hall (2008); and Long (2009). For recently published actual cases with discussion of how the cases have been used in the classroom, see Cochran (2004); Cattani (2005); Ernst and Schmidt (2005); Lawrence and Henderson (2005); Van Wassenhove and Guide (2008); and Yin et al. (2008).

Evidence of the effectiveness of the case approach across cultures is also gradually accumulating. In one example, Gonzalez (2008) and her colleagues in the Departamento de Modelación Industrial of the Universidad de Talca recently designed operations research programmes with a heavy case orientation and are extremely excited about their results. Gonzalez and her colleagues committed to a case orientation for these new programmes after attending workshops at the $1^{\text {st }}$ ALIO/INFORMS Teaching Effectiveness Colloquium in 2006. It is worth considering (and investigating scientifically) that the case approach may work best in cultures with strong folklore traditions.

It is important to note that one factor inhibiting the widespread use of operations re- 
search cases has been the lack of available cases with secure teaching notes. INFORMS Transactions on Education (an open access online journal on operations research education published by INFORMS) has attempted to address this situation by establishing a password protected site for the case teaching notes it publishes. Cases published by INFORMS Transactions on Education now comprised three distinct components:

- The case narrative (this is open to the public and is what is generally distributed to students);

- An article that describes the development, pedagogical objectives, and potential classroom uses of the case narrative (this is also open to the public); and

- Detailed teaching notes associated with the case narrative (these are available through a password protected site and are intended solely for the express use of classroom instructors who have been vetted ${ }^{1}$ by INFORMS Transactions on Education).

For recently published actual cases with downloadable detailed teaching notes, see for example Agrawal et al. (2009); Anderson et al. (2008); Ferguson and Queenan (2009); Köksalan and Batun (2009); Metters et al. (2009); and Shumsky (2009).

Cases are also a popular tool among operations research instructors in Europe, and three North American Business Colleges (the Richard Ivey School at the University of Western Ontario, the Darden School at the University of Virginia, and the Harvard Business School) rely exclusively on the case approach.

\subsection{Projects}

Still other instructors strive to give their students an even more complex and realistic modelling experience. Many of these instructors look outside their classrooms to organizations with problems that the instructors can assign as projects to their students. In an approach similar to that taken by many undergraduate engineering programs, these instructors often offer a senior design course in which student teams use operations research to resolve a problem faced by an external organization. The projects are provided by organizations in the private, government, and not-for-profit sectors (some projects are actually provided by the university).

Fraiman (2002) established the critical role that can be played by projects in developing relationships between operations research and its potential stakeholders. He provides details of outreach programs in the Columbia Business School, focusing specifically on the benefits to academia and industry. Fraiman emphasizes the dependence of success of this outreach on the alignment of faculty research interests to create the critical mass of expertise necessary to attract industry partners. He also explains that establishing this critical mass eventually required close collaboration between Columbia and other universities.

Larson (2002) described the importance of developing the related skills of framing, formulating, and solving problems, and he stressed doing so "in-the-large." He describes

\footnotetext{
${ }^{1}$ Instructors may contact Randy Kiefer (randy.kiefer@INFORMS.ORG) to obtain access to the Case Teaching Notes page.
} 
the use of projects both as part of operations research courses and in a novel and laudable semester-long doctoral "practicum." Grossman (2002a) highlights the benefits of student consulting projects, which includes providing students an opportunity to i) apply operations research/management science tools to real complex problems and ii) obtain insight into the ways that organizations function. Grossman also cites benefits to the faculty, which include receiving clear feedback on her/his students' capabilities, establishing a broad connection to local industry, and obtaining material through these projects for the development of concrete examples, case studies, and academic research projects. In addition to the end results of the student analyses, the organizations that provide the projects also benefit from the potential stimulation of a new internal perspective on the organizations problems and activities.

Armacost and Lowe (2003) explain how the semester-long operations research capstone course they teach at the U.S. Air Force Academy evolved from a case study-driven course to one in which students serve as OR consultants for a variety of clients in the Air Force and Colorado Springs communities. The authors indicate that in addition to providing an outstanding educational experience for their students, this course provides a valuable service to the community. Camm (2008) provides similar details on the use of projects in the programs at the University of Cincinnati.

Lewis and Sexton (2005) describe a novel design for incorporating group projects in courses when an adequate number of projects from external sources is not available. In their approach, students are placed into teams and each student team is assigned two projects. For one of these projects the group acts as the client who is interested in purchasing the DSS under development by a second group. For the other of these projects the group acts as the developer of a DSS that is under consideration for purchase by a third group. The authors explain how their approach can be used, in the absence of available external projects, to provide students with the opportunity to experience technical and managerial aspects of decision support system development from the perspectives of both the buyer and the seller.

Some research, such as the work by Griffin et al. (2004) on the impact of group size and project duration on student learning in project based capstone courses, has been published on various aspects of project based course design. However, there is still a need for systematic consideration of other characteristics of project based courses and their impact on student learning.

\subsection{Interdisciplinary course development}

One of the most appealing and prominent features of operations research is its inherent interdisciplinary nature. Operations researchers commonly draw from a wide variety of disciplines including engineering, economics, logic, computer science, statistics, psychology, probability, and other social and behavioral sciences. Applications are commonly found in finance, marketing, engineering, accounting, information systems, politics, medicine, sports, and production/operations management. In recent years several operations research instructors have concluded that they can provide an operations research course with greater appeal if they focus on applications to a specific discipline. 
Winston (2001) documents his efforts to provide executive education in application of spreadsheet modelling, optimization, Monte Carlo simulation and data analysis to financial analysts. The impressive list of corporations that have utilized Winston's services include Microsoft, Cinergy, Intel, Cisco, GM, Ford, Eli Lilly, Pfizer, NCR, Arthur Andersen, the U.S. Army, and PricewaterhouseCoopers. Andriole and Nydick (2005) discuss their integration of undergraduate courses in management science and management information systems into a single project oriented course. The authors explain that their motivation was to exploit the synergy between the analytical approaches to modelling, decision-making, and project management common to management science courses with business technology management's rigorous models, methods, tools, and techniques. Andriole and Nydick also document several examples of how management science methods, tools, and techniques have been used by students through this course to solve real business technology management problems.

Some particularly exciting efforts to encourage the application of operations research to problems in health and medicine have developed. Novoa and Cliff (1990) discuss their efforts to train Mozambican medical students in operational research. Kahn et al. (2007) review their efforts to developing regional operations research training capacity in south Asia. The Pan African Thoracic Society (2009) recently conducted a course on methods in epidemiologic, clinical, and operations research in Blantyre, Malawi. The International Union Against Tuberculosis and Lung Disease (2009) recently announced that it was launching a program of half-day symposia to be presented at several conferences as well as a related three-module course that was developed and is to be taught in collaboration with Médecins Sans Frontières.

Again, these results suggest a research opportunity; a scientific investigation into why some interdisciplinary operations research courses succeed while others fail would be a welcome contribution to the understanding of operations research pedagogy.

\subsection{Software}

The first operations research software to gain widespread personal computer usage for the classroom was Lindo. First offered in 1979, the original Lindo software allowed for a straightforward equation style of model expression for mathematical programming problems. A few years later, spreadsheet-based optimization software such as What'sBest! and Solver were introduced. Spreadsheet optimization software eliminated the necessity of formal algebraic formulations, and an intense debate emerged in the operations research academic community over which approach was more effective and pedagogically appropriate.

As spreadsheets gained ubiquity and became readily available to students, a greater number of operations research instructors began to take advantage of the flexibility and relative ease of use of spreadsheet solvers. Plane $(1994,1997)$ wrote on using spreadsheets to engage students in creating spreadsheet models for production and operations management. Ragsdale (1995) and Plane (1996) soon published early operations research textbooks that utilized spreadsheets. By the end of the decade several other operations research textbooks that featured a spreadsheet approach were published. These include Winston 
et al. (1996); Hesse (1997); Camm and Evans (1997); Eppen et al. (1998); Evans and Olsen (1998); Lawrence and Pasternack (1998); and Anderson et al. (1999).

While many authors published operations research textbooks that incorporated spreadsheets, the discipline was (and still is) far from unanimous in its embrace of the new technology. Vazsonyi (1993), Conway and Ragsdale (1997), Powell (1997b), Savage (1997), Troxell (2002), and Kadijevich (2009) contributed particularly thoughtful discourses on the potential advantages and disadvantages of the use of spreadsheets to teach operations research.

Eventually the majority of educators in the discipline came to appreciate the distinct pedagogical advantages of spreadsheets (although this is still by no means a unanimously held opinion). Contributing to this movement were Bodily (1986), Carraway and Clyman (2000), and Winston (1996), who documented their integration of spreadsheets into quantitative methods courses for MBA students; Leon et al. (1996); Leon et al. (2006), Erkut (1998), Thiriez (2001, 2004), Grossman (2002b, 2003, 2006), and LeBlanc and Grossman (2008), who provided guidelines for effective use of spreadsheets in operations research courses; and Ragsdale (2003), Baker and Camm (2005), Raffensperger and Richard (2005), Markham and Palocsay (2006), Pachamanova (2006), and Munisamy (2009), who each provided guidelines for using spreadsheets to teach students about specific operations research models. While many academicians have investigated the efficacy of the spreadsheet approach to operations research education, there is certainly still room for a systematic study of this issue.

\subsection{Support initiatives}

In the 1990s many volunteers began to establish various sustainable means of supporting efforts to improve operations research education. The first of these organized efforts occurred in 1995, when seven members of INFORMS who wanted a forum for the discussion of operations research pedagogy started a group called INFORM- $E D$ (2009). In its fifteen years of existence, INFORM-ED has grown to over four hundred members, many of whom live outside of North America. The forum now sponsors workshops, colloquia, education oriented conference sessions, and case writing competitions for individuals interested in the teaching of operations research and the management sciences at the university level (Bell, 1998).

In addition to organizing operations research education sessions for the annual INFORMS conference and other conferences worldwide, activities sponsored by INFORM-ED include the annual Teaching Case Competition (TCC) and annual Teaching Effectiveness Colloquium (TEC). The TCC was established by the author in 2000 and has been held for ten consecutive years. Each year four finalists are selected from the TCC submissions, and the finalists present their cases in special sessions at the annual INFORMS Conference.

The TEC was established by the author in 1999 and has been held for eleven consecutive years. This two-day colloquium comprises hands-on workshops on innovative and effective approaches to various issues in operations research education. Topics that have been 
featured include:

- active learning,

- using classroom cases,

- project based learning,

- effective use of spreadsheets,

- integrating projects into courses,

- managing large classrooms,

- teaching across cultures,

- performing educational research and experiments,

- developing students' critical thinking skills,

- developing students' oral and/or written communication skills,

- integrating other disciplines (e.g., finance, marketing, etc.) into OR courses, and

- teaching modelling skills.

The annual TEC generally attracts 30-40 participants, and the relatively intimate atmosphere fosters a great deal of valuable discourse among the participants.

INFORMS also sponsored a series of summer Teaching Management Science Workshops (2009) from 2004 through 2007. These very popular and successful three day workshops, which were generally held at relatively secluded venues, provided a more intense experience than the TEC.

In 2005 INFORMS agreed to sponsor TECs for operations research conferences hosted by societies from developing nations (the International Federation of Operations Research Societies (IFORS) agreed to join this initiative in 2007). The funds provided by these two organizations are used to bring several (generally three to five) INFORMS and IFORS representatives to the host conference to give workshops as part of a TEC. The host organization pays for the local expenses for these individuals, recruits a similar number of its members to give workshops, and promotes and provides the venue for the TEC. The purposes of these international TEC are to (i) enhance the quality of quantitative education, (ii) encourage the application of quantitative methods, (iii) support the development of cross-cultural exchanges and professional relationships, and (iv) foster the establishment of a supportive international network of operations research educators. To date, these annual International TEC have been held in:

- Montevideo, Uruguay in November 2006 with the XIII CLAIO 2006 Latin-IberoAmerican Conference on Operations Research — this was a joint education initiative of INFORMS and the Latin American Ibero Association on Operations Research (ALIO).

- Cape Town, South Africa in September 2007 with the 2007 ORPA/ORSSA (Operations Research Practice in Africa/Operations Research Society of South Africa) Conference - this was a joint education initiative of INFORMS, IFORS, the Association of European Operational Research Societies (EURO), ORPA, and ORSSA.

- Cartagena de Indias, Colombia in September 2008 with the 2008 Latin-Ibero-American Conference on Operations Research (XIV CLAIO) - this was another joint education initiative of INFORMS, IFORS, and the ALIO. 
Another very successful innovation in operations research education has been the High School Operations Research Outreach (HSOR) project (Edwards and Chelst, 2004). Through this initiative the authors and their colleagues attempt to address issues of attracting the next generation of operations researchers and building a base of consumers of operations research studies. Through this programme, which is a project of INFORMS and Wayne State University that was funded by a grant from the National Security Agency, this team (with Ret. Col. Frank Trippi) has created self-contained supplements on topics such as linear programming, decision trees, and queuing. These modules can supplement either a traditional high school mathematics curriculum or a high school curriculum based on new National Council of Teachers of Mathematics (NCTM) guidelines. The modules have been published in the book Does This Line Ever Move? Everyday Applications of Operations Research (Chelst and Edwards, 2005) and can be accessed on the Internet ${ }^{2}$. A Spanish version, Avanzará esta fila alguna vez? Aplicación de la Investigación de Operaciones," has been created (Chelst and Edwards, 2008) with the support of the Chilean Operational Research Society Instituto Chileno de Investigacion de Operaciones (ICHIO). Edwards, Chelst, and their team also work with other operations research professionals to coordinate and conduct workshops that are designed to help high school teachers effectively accomplish this integration. The author participated in a recent workshop given by this group to San Diego, California high school mathematics teachers and was extremely impressed by the enthusiasm of the audience and effectiveness of the program.

In 2004 Claude Yugma of Ecole des Mines de Saint-Etienne, Serigne Gueye of Université Havre, and Eric Soubeiga of Chamonix Private Equity established ORPA. Since its establishment, ORPA has organized (generally) annual meetings of operations research professionals from Africa, Europe, and North America. The ORPA conferences have included:

- ORPA 1 - the First Conference on OR Practice in Africa, April 7-8, 2005 in Ouagadougou, Burkina Faso (hosted by Prime Minister H. E. Dr Paramanga E. Yonli);

- ORPA 2 - Improving Governance 6 Enhancing Policymaking in Africa, June 6-7, 2006 in London, UK;

- ORPA 3 - Improving Governance 83 Enhancing Policymaking in Africa, June 67, 2007 in Cape Town, South Africa. This ORPA conference featured one of the international TECs referred to a few paragraphs earlier; and

- ORPA 4 - Using Operations Research to Address Urban Transport and Water Resource Management Issues in Africa, October 10-11, 2008 in Washington, D.C. (immediately preceding the 2008 INFORMS conference). This ORPA conference was co-sponsored by SAS, IBM, INFORMS, IFORS, and the American Statistical Association (ASA).

One outcome of the ORPA 3 conference in Cape Town was the establishment of the Network of Operations Research Educators for Africa (NOREA) ${ }^{3}$. The objective of this

\footnotetext{
${ }^{2}$ Teachers can request copies by phoning Trippi at (703) 922-6775 or calling toll-free at (800) 4INFORMS.

${ }^{3}$ NOREA is administered by Neil Manson (of the School of Information Technology, Monash South Africa). Anyone can join and contribute to this Yahoo group free of charge.
} 
network is to promote and assist the teaching of operations research to students in Africa. This group accomplishes its objective by providing resources and links to other publicly available resources that are useful in teaching operations research and stimulating innovative and effective teaching. NOREA also provides opportunities for collaboration and sharing of ideas between operations research educators.

On a much larger scale, a partnership between the three universities in South Africa's Western Cape (University of Cape Town, Stellenbosch University, and University of the Western Cape) and three European universities (Cambridge University, Oxford University, and Université Paris-Sud-XI) has produced the African Institute for Mathematical Sciences (AIMS). Established in 2003, AIMS is a centre for postgraduate study in Muizenberg (a suburb of Cape Town, South Africa) that prepares students for research and teaching careers in the quantitative sciences. The primary objectives of AIMS are to:

- promote mathematics and science in Africa;

- recruit and train talented students and teachers; and

- build capacity for African initiatives in education, research, and technology.

The centre recruits students from all over Africa for an intensive nine month program of courses, taught by outstanding African and international lecturers, designed to build research skills through exposure to cutting-edge topics. The program develops strong mathematical and computing problem-solving skills and leads to a postgraduate diploma in the Mathematical Sciences that is formally accredited by the three partner South African Universities. Graduates generally go on to advanced academic programs in a wide range of scientific fields or to careers in education, industry, or government.

Finally, INFORMS publishes INFORMS Transactions on Education, a peer-reviewed open access electronic journal whose mission is to advance operations research/management science education at all levels worldwide. INFORMS Transactions on Education fulfills its mission by encouraging the creation and facilitating the dissemination of information, ideas, software, data sets, and other educational materials useful to operations research/management science instructors. The journal publishes high-quality articles in a variety of areas related to the teaching of operations research/management science: cases, spreadsheet applications, review and opinion articles, resource reviews, and discussions of the impact of new technologies and new methods of assessment on operations research/management science education. The electronic format of the journal allows innovations in content and reader involvement not possible in a print journal, such as immediate electronic access to data sets, software, Java applications, interactive graphics, multimedia applications, hypertext links, and full-text searching. As the Editor-in-Chief of INFORMS Transactions on Education, the author encourages the operations research community to browse through current and past issues, where it is very likely that a reader will find several articles that will help an instructor improve the delivery of operations research/management science in her/his classroom. He also encourages members of the operations research community to submit articles for review to INFORMS Transactions on Education on their innovative approaches to operations research/management science education. 


\section{Where should operations research pedagogy go?}

This is an exciting time for operations research/management science education. The efforts of the last twenty years, in combination with recent technological advances and the increasing scarcity of resources (which has dramatically increased the need for advanced analytical thinking), have put the discipline in an advantageous position. Operations research is poised for rapid and sustained growth, which it can achieve if the discipline can establish a strong identity with its potential stakeholders.

Education must be an integral component of any strategy designed to help operations research achieve its potential; it is imperative that the discipline continue to focus on:

- education/production of the next generation of analysts and users;

- collaboration across cultures/development of a stronger international operations research community; and

- applications to societal and humanitarian issues.

A critical component of this strategy is the ongoing organization and participation in conferences and teaching effectiveness colloquia in developing nations. Fortunately, many such activities are planned for the next few years.

The International TEC series goes to Jaipur, India in December for the 2009 APORS (Association of Asian Pacific Operational Research Societies) conference. Several extended workshops, given by recognized leaders in operations research education from around the world, on innovative and effective approaches to operations research, will make up this TEC. Tentative planning is also underway for an International TEC to be held in conjunction with the 2011 Operations Research Society of East Africa (ORSEA) Conference in Nairobi, Kenya.

The $9^{\text {th }}$ International Conference on Operations Research (ICOR) will feature the $1^{\text {st }}$ ICOR TEC on February 23-24, 2010. This TEC will also consist of several extended workshops, given by recognized leaders in operations research education from around the world, on innovative and effective approaches to operations research. The conference and TEC will be held at Colegio San Jerónimo de La Habana, Havana, Cuba. In a true international effort, the conference is organized by Universidad de La Habana and SAMOSUniversité Paris 1 (Panthéon-Sorbonne), and sponsored by Asociación Latinoamericana de Investigación de Operaciones (ALIO); Humboldt Universität zu Berlin; Ministerio de Ciencias Tecnología y Medio Ambiente; Oficina del Historiador de La Ciudad; and Sección Científica de Investigación Operacional, Sociedad Cubana de Matemática y Computación.

ORPA is planning and organizing ORPA 5 for 2010. This conference, scheduled for March 18-20, 2010, promises to feature an extensive educational component. ORPA 5 will be held in Dakar, Sénégal, hosted by Université Cheikh Anta Diop, and co-chaired by Babacar Ndiaye and Diaraf Seck. Another TEC is planned for the June 2010 ALIO/INFORMS Joint International Meeting, to be co-sponsored by the ALIO and INFORMS and hosted by the Sociedad Argentina de Informática. 
In a different approach, ORPA has proposed the pan-African School of Decision Sciences (ASDS). The mission of this proposed school is to:

- strengthen capacity of African leadership by providing current and future policy makers and decision makers in the public and private sectors with the ability to make scientifically informed decisions, particularly through the use of the latest technological advances in operations research, computer science, and information technology;

- reverse the African "brain drain" by promoting an African cross-continental knowledge/technology transfer through participation of the African Diaspora in the School's teaching activities; and

- create, develop and stimulate an Africa-wide market for job creation and professional development in the fields of operations research, computer science, information technology, and related disciplines.

ASDS will work toward these objectives by offering traditional courses that will lead to an ASDS masters programme in Decision Sciences; providing short courses as part of professional training and development programs for executives in African institutions, African governments and African businesses; and engaging in scientific research and consultancy. The founders of ASDS are now actively looking for sponsors.

Finally, operations research must devote more energy to pedagogical research and its wide dissemination at conferences and in journals such as INFORMS Transactions on Education (Llewellyn, 2006, 2007; Hardin et al., 2008; American Society for Engineering Education, 2009). Such activities will not only serve to assist operations research instructors in their efforts to improve the quality of their instruction (with the hope of improving their students' comprehension and long term retention of operations research concepts), they will serve as examples of important and meaningful applications of the discipline.

Ultimately the operations research community must consider how to simultaneously promote (i) education/production of the next generation of analysts and users, (ii) collaboration across cultures/development of a stronger international operations research community, and (iii) applications to societal and humanitarian issues. For several years the author has advocated the use of active learning to initially engage students in operations research, progressively more complex cases to foster a strong understanding and appreciation of operations research as students advance through their academic programs, and project based learning as the student nears completion of her/his degree programme to move the student to apply what s/he has learned beyond the classroom (Cochran, 2009). Instructors can then (i) publish related papers in peer reviewed academic journals that have an application orientation (such as Interfaces, the Journal of the Operational Research Society, or ORiON), (ii) write classroom cases based on these projects, and (iii) publish these cases (with detailed teaching notes) in INFORMS Transactions on Education.

If a fair proportion of these projects involve applications to societal and humanitarian issues (and a plethora of such projects do exist), both students and clients will develop a strong appreciation for the potential of operations research. Of course, this approach necessitates a strong emphasis on the development of modelling, analytic, and critical thinking skills and should be supported with appropriate operations research software. 
Implementation of the strategy described here will require a coordinated effort by all segments of the operations research community - academicians, policy makers, administrators, government officials, and business people. Each individual in the operations research community has an important role to play in educating the discipline's potential stakeholders. As stated earlier, everyone in the operations research community - even those not in academia - is an instructor of operations research in some manner. Furthermore, each individual in the operations research community has a vested interest in increasing understanding appreciation of operations research among the discipline's potential stakeholders. While the discipline of operations research may have arose from the most catastrophic war in history (Kirby, 2003; Rau, 2005), it has much to offer those who work in the interest of development and sustainable improvement of quality of life. Operations research is poised for a great future, and its contribution to education is the key to the realization of the discipline's enormous potential.

\section{References}

[1] ACKOFF RL, 1979a, The future of operational research is past, Journal of the Operational Research Society, 30(1), pp. 93-104.

[2] Ackoff RL, 1979b, Resurrecting the future of operational research, Journal of the Operational Research Society, 30(3), pp. 189-99.

[3] ACKOFf RL, 1987, Presidents' symposium: OR, a post mortem, Operations Research, 35(3), pp. 471-474.

[4] Agrawal N, Cohen MA \& Gans N, 2009, Revenue management at Harrah's Entertainment, Inc. INFORMS Transactions on Education, 9(3), pp. 158-179.

[5] American Society for Engineering Education, 2009, Creating a culture for scholarly and systematic innovation in engineering education - Ensuring U.S. engineering has the right people with the right talent for a global society: Phase 1 Report, [Online], [Cited July 27 ${ }^{\text {th }}, 2009$ ]. Available from www . asee.org/about/board/committees/EEGE/upload/CCSSIEE_Phase1Report_June2009.pdf.

[6] Anderson CK, Wilson JG \& Zhang G, 2008, Bidding on Priceline, INFORMS Transactions on Education, 9(1), pp. 35-45.

[7] Anderson DR, Sweeney DJ \& Williams TA, 1976, Introduction to management science: Quantitative approaches to decision making, $1^{\text {st }}$ Edition, West Publishing, St. Paul (MN).

[8] Anderson DR, Sweeney DJ \& Williams TA, 1994, Introduction to management science: Quantitative approaches to decision making, $8^{\text {th }}$ Edition, West Publishing, St. Paul (MN).

[9] Anderson DR, Sweeney DJ \& Williams TA, 1999, Contemporary management science: With spreadsheets, South-Western College Publishing, Cincinnati $(\mathrm{OH})$.

[10] Anderson DR, Sweeney DJ, Williams TA, Camm JD \& Martin K, 2006, Quantitative methods for business, $11^{\text {th }}$ edition, South-Western/Cengage Learning, Cincinnati $(\mathrm{OH})$.

[11] Andriole SJ \& Nydick RL, 2005, Business technology management: A case study, INFORMS Transactions on Education, 6(1), pp. 13-20.

[12] Armacost AP \& Lowe JK, 2003, Operations research capstone course: A project-based process of discovery and application, INFORMS Transactions on Education, 3(2), pp. 1-25.

[13] BAKER KR \& CAMM JD, 2005, On the use of integer programming versus evolutionary solver in spreadsheet optimization, INFORMS Transactions on Education, 5(3), pp. 1-7.

[14] BALEZ M, 2004, Operations research gives profession a bad name, ORMS Today, 31(1), p. 21.

[15] Bell PC, 1997, Positioning the OR/MS core course, ORMS Today, 24(3), pp. 8-10.

[16] BeLl PC, 1998, Teachers' aid from INFORMS, ORMS Today, 25(5), p. 12.

[17] Bell PC \& von Lanzenauer CH, 2000, Teaching objectives: The value of using cases in teaching operational research, Journal of the Operational Research Society, 51, pp. 1367-1377. 
[18] Bierman H, Bonini CP \& Hausman WH, 1961, Quantitative analysis for business decisions, Irwin, Chicago (IL).

[19] Bodily SE, 1986, Spreadsheet modeling as a stepping stone, Interfaces, 16(5), pp. 34-52.

[20] Bodily SE, 1996, Teaching MBA quantitative business analysis with cases, Interfaces, 26(6), pp. $132-138$.

[21] Brimberg J \& Hurley B, 2007, Solving the U2 brainteaser with integer and dynamic programming, INFORMS Transactions on Education, 7(3), pp. 223-227.

[22] Brown G \& Atkins M, 1988, Effective teaching in higher education, Methuen \& Co., New York $(\mathrm{NY})$.

[23] Buffa ES \& Dyer JS, 1978, Essentials of management science / operations research, John Wiley \& Sons, New York (NY).

[24] CAMM JD, 2008, OR in the classroom - Get real!, ORMS Today, 35(4) pp. 34-37.

[25] Camm JD \& Evans JR, 1997, Management science: Modeling, analysis and interpretation, SouthWestern College Publishing, Cincinnati $(\mathrm{OH})$.

[26] Campbell WE \& Smith KA (Eds.), 1995, New paradigms for college teaching, Jossey-Bass Publishers, San Francisco (CA).

[27] CARRAway RL \& Clyman DR, 2000, Integrating spreadsheets into a case-based MBA quantitative methods course: Real managers make real decisions, INFORMS Transactions on Education, $\mathbf{1}(\mathbf{1})$, pp. 38-46.

[28] Cashin WE, 1985, Improving lectures. IDEA Paper No. 14, Kansas State University Center for Faculty Evaluation and Development, Manhattan (KS).

[29] Cattani K, 2005, Hewlett-Packard company: Managing product end of life, Operations Management Education Review, 1, pp. 67-86.

[30] Chelst KR \& Edwards TG, 2005, Does this line ever move? Everyday applications of operations research, Key Curriculum Press, Emeryville (CA).

[31] Chelst KR \& Edwards TG, 2008. ¿Avanzara esta fila alguna vez? aplicaciones de la investigacion de operaciones, Editorial Universitaria, Santiago.

[32] Chickering AW \& Gamson ZF, 1987, Seven principles for good practice, American Association for Higher Education Bulletin, 39, pp. 3-7.

[33] Chilcont GW, 1989, Instructional behaviors for clearer presentations in the classroom, Instructional Science, 18, pp. 289-314.

[34] Churchman CW, Ackoff RL \& Arnoff EL, 1957, Introduction to operations research, John Wiley, New York (NY).

[35] Čibej JA, 2002, Operations research education for forgotten populations, European Journal of Operational Research, 140(2), pp. 225-231.

[36] Cochran JJ, 2000, Successful use of cases in introductory undergraduate business college operations research courses, Journal of the Operational Research Society, 51(12), pp. 1378-1385.

[37] Cochran JJ, 2001a, Probability, stats $\&$ playing games, ORMS Today, 28(2), p. 14.

[38] Cochran JJ, 2001b, Who Wants To Be A Millionaire ${ }^{\circledR}$ : The classroom edition, INFORMS Transactions on Education, 1(3), pp. 112-116.

[39] Cochran JJ, 2004, Bowie Kuhn's worst nightmare, INFORMS Transactions on Education, 5(1), pp. 18-36.

[40] Cochran JJ, 2009, Keys to expanding OR discipline - Educating students, colleagues and industry: A three-pronged approach to increasing awareness of and appreciation for operations research, ORMS Today, 36(4), pp. 44-48.

[41] Conway DG \& Ragsdale CT, 1997, Modeling optimization problems in the unstructured world of spreadsheets, Omega, 25(3), pp. 313-322.

[42] Cook TM, 2003, Revised MBS guidelines, ORMS Today, 30(3), p. 6.

[43] Cook TM \& Russell RA, 1981, Introduction to management science, $2^{\text {nd }}$ Edition, Prentice Hall, Upper Saddle River (NJ).

[44] Corbett CJ \& VAn Wassenhove LN, 1993, The natural drift: What happened to operations research? Operations Research, 41(4), pp. 625-640. 
[45] DePuy GW \& TAYlOR GD, 2007, Using board puzzles to teach operations research, INFORMS Transactions on Education, 7(2), pp 160-168.

[46] Edwards TG \& Chelst KR, 2004, The HSOR project: Insinuating OR into high school mathematics classrooms, INFORMS Transactions on Education, 4(3), pp. 1-8.

[47] EILON S, 1980, The role of management science, Journal of the Operational Research Society, 31(1), pp. 17-28.

[48] Eppen G, Gould FJ \& Schmidt CP, 1987, Introductory management science, $2^{\text {nd }}$ Edition, Prentice Hall, Upper Saddle River (NJ).

[49] Eppen G, Gould FJ, Schmidt CP, Moore J \& Weatherford L, 1998, Introductory management science: Decision modelling with spreadsheets, $5^{\text {th }}$ Edition, Prentice Hall, Upper Saddle River (NJ).

[50] ERKut E, 1998, How to 'excel' in teaching management science, ORMS Today, 25(5), pp. 40-43.

[51] ERnst R \& Schmidt GM, 2005, Benihana: A new look at an old classic, Operations Management Education Review, 1, pp. 5-28.

[52] Evans JR \& OLSEN DL, 1998, Introduction to simulation and risk analysis, Prentice Hall, Upper Saddle River (NJ).

[53] Ferguson M \& QueEnan C, 2009, Starting with good inputs: Unconstraining demand data in revenue management, INFORMS Transactions on Education, 9(3), pp. 180-187.

[54] Fraiman NM, 2002, Building relationships between universities and businesses: The case at Columbia Business School, Interfaces, 32(2), pp. 52-55.

[55] Funes M, 2008, Experiencias Innovadoras en la Ensñenanza de I.O., XXII Encuentro Nacional de Docentes de Investigación Operativa (XXIIENDIO) and XX Escuela de Perfeccionamiento en Investigación Operativa (XX EPIO), Universidad Teconológica Nacional - Regional Buenos Aires.

[56] Garfield J, 1993, Teaching statistics using small-group cooperative learning, Journal of Statistics Education, 1(1), [Online journal], [Cited June $6^{\text {th }}, 2009$ ]. Available from http://www . amstat .org/ publications/jse/v1n1/garfield.html.

[57] Gass SI, 1990, Model world: Danger, beware the user as modeler, Interfaces, 20(3), pp. 60-64.

[58] Gavirneni S, 2006, Teaching data envelopment analysis using Applichem - New perspective on a popular operations case, INFORMS Transactions on Education, 6(3), pp. 38-45.

[59] Geoffrion AG, 1997, Maxims for modelers, [Online], [Cited June 14 $4^{\text {th }}$, 2009], Available from www. anderson.ucla.edu/faculty/art.geoffrion/home/docs/Gudmdlg2.htm.

[60] Giraud G, 1997, Cooperative learning and statistics instruction, Journal of Statistics Education, 5(3), [Online journal], [Cited June 10 ${ }^{\text {th }}, 2009$ ], Available from http://www.amstat.org/ publications/jse/v5n3/giraud.html.

[61] Gnanadesikan M, Scheaffer RL, Watkins AE \& Witmer JA, 1997, An activity based statistics course, Journal of Statistics Education, 5(2), [Online journal], [Cited June 25 ${ }^{\text {th }}$, 2009], Available from http://www . amstat.org/publications/jse/v5n2/gnanadesikan.html.

[62] Gonzalez M, 2008, Experiencias en el rediseño e implementación de los cursos de Investigación de Operaciones en la la carrera de Ingeniería Industrial, Paper presented at the XIV Latin-IberoAmerican Congress on Operations Research, Cartagena.

[63] Griffin PM, GRIfFin SO \& Llewellyn DC, 2004, The impact of group size and project duration on capstone design, Journal of Engineering Education, 93(3), pp. 185-193.

[64] Grossman TA, 2001, Causes of the decline of the business school management science course, INFORMS Transactions on Education, 1(2), pp. 51-61.

[65] Grossman TA, 2002a, Student consulting projects benefit faculty and industry, Interfaces, 32(2), pp. $42-48$.

[66] Grossman TA, 2002b, Spreadsheet engineering: A research framework, Proceedings of the Third Symposium of the European Spreadsheet Risks Interest Group, Cardiff, available from http:// aps. arxiv. org/ftp/arxiv/papers/0711/0711.0538.pdf.

[67] Grossman TA, 2003, Spreadsheet modeling is a strategic opportunity, ORMS Today, 30(5), pp. $12-14$.

[68] Grossman TA, 2006, The spreadsheet analytic value chain, ORMS Today, 33(4), pp. 24-25. 
[69] HALL OP, 2008, Learning support systems for management education: Screening for success, MERLOT Journal of Online Learning and Teaching, 4(3), pp. 277-290.

[70] Hannibalsson I, 2001, Course correction - Classroom case study: University of Iceland professor increases interactive teaching in operations management to meet changing demands of students, ORMS Today, 28(4), pp. 40-43.

[71] Hardin J, Lowe J, Rader D \& Llewellyn DC, 2008, Teaching colloquium, ORMS Today, 35(3), p. 10.

[72] Hartley J \& Cameron A, 1967, Some observations on the efficiency of lecturing, Educational Review, 20, pp. 30-37.

[73] Hartley J \& Davies IK, 1978, Note-taking: A critical review, Programmed Learning and Educational Technology, 15, pp. 207-224.

[74] Hesse R, 1974a, Sesame Street for decision sciences: Part I - Problems, Decision Sciences, 5(4), pp. 654-659.

[75] Hesse R, 1974b, Sesame Street for decision sciences: Part II - Some designs for integrated decision sciences and organizational behavior, Decision Sciences, 5(4), pp. 659-663.

[76] Hesse R, 1997, Managerial spreadsheet modeling and analysis, Irwin, Homewood (IL).

[77] Hillier FS \& Lieberman GJ, 1980, Introduction to operations research, $3^{\text {rd }}$ Edition, Holden-Day, San Francisco (CA).

[78] Horner P, 2002, Preaching what he practices - QESA: INFORMS President-elect Tom Cook plans to focus on marketing the profession and educating consumers, ORMS Today, 29(6), pp. 20-23.

[79] Horner P, 2003, The science of better, ORMS Today, 30(6), pp. 20-23.

[80] Horowitz I, 1965, An introduction to quantitative business analysis, McGraw-Hill, New York (NY).

[81] INFORMS Business School EducAtion TASK ForCE, 1996, The report of the operating subcommittee of the INFORMS business school education task force, [Online], [Cited May 21 ${ }^{\text {st }}, 2009$ ], Available from http://education.forum.informs.org//magnanti.html.

[82] INFORMS Education Committee, 1995, Report of a survey of OR/MS programs, ORMS Today, 21(1), pp. 54-56.

[83] International Union Against Tuberculosis and Lung Disease, 2009, [Online], [Cited October 22 ${ }^{\text {nd }}$, 2009], Available from http://www.theunion.org/news/operational-researchtraining-programmes-launched.html.

[84] KAdiJEvich D, 2009, Simple spreadsheet modeling by first-year business undergraduate students: Difficulties in the transition from real world problem statement to mathematical model, Projects 144032D and 144050A funded by the Serbian Ministry of Science, [Online], [Cited July 22 ${ }^{\text {nd }}, 2009$ ], Available from http://tsg.icme11.org/document/get/450.

[85] Khan ME, Foreit J, Roychowdhury S, Ram F \& Shekhar C, Developing regional operations research training capacity in South Asia, The Population Council, [Online], [Cited October 22, 2009], Available from www.popcouncil.org/pdfs/frontiers/FR_FinalReports/Asia_ RegionalCapBuild.pdf.

[86] KeEler CM \& Steinhorst RK, 1995, Using small groups to promote active learning in the introductory statistics course: A report from the field, Journal of Statistics Education, 3(2), [Online journal], [Cited June $6^{\text {th }}, 2009$ ], Available from http://www .amstat.org/publications/jse/v3n2/ keeler.html.

[87] Kendall MG, 1958, The teaching of operational research: Presidential address to the Operational Research Society, Operational Research Quarterly, 9(4), pp. 265-278.

[88] Kirby MW, 2003, Operational research in war and peace: the British experience from the 1930 s to 1970, Imperial College Press, London.

[89] KöKsalan M \& Batun S, 2009, Assigning regions to sales representatives at Pfizer Turkey, INFORMS Transactions on Education, 9(2), pp. 70-83.

[90] LAPIn LL, 1980, Management science for business decisions, Harcourt Brace Jovanovich, New York $(\mathrm{NY})$.

[91] LAPIN LL, 1994, Quantitative decision making for business decisions, $6^{\text {th }}$ Edition, Duxbury, Belmont $(\mathrm{CA})$. 
[92] LAPIN LL \& WHISLER WD, 2002, Quantitative decision making with spreadsheet applications, $7^{\text {th }}$ Edition, Duxbury, Belmont (CA).

[93] LARson RC, 2002, Frame, formulate and solve, ORMS Today, 29(4), pp. 26-29.

[94] Lawrence JA \& PASTERnACK BA, 1998, Applied management science: A computer-integrated approach for decision making, John Wiley \& Sons, New York (NY).

[95] Lawrence JJ \& Henderson KM, 2005, Mount Michael Vineyard: Choosing a high quality closure, Operations Management Education Review, 1, pp. 29-66.

[96] LeBlanc L \& Grossman TA, 2008, The use of spreadsheet software in the application of management science and operations research, Interfaces, 38(4), pp. 225-227.

[97] LeOn L, PrZAsnyski ZH \& SeAl KC, 1996, Spreadsheets and OR/MS models: An end-user perspective, Interfaces, 26(2), pp. 92-104.

[98] LeOn L, Seal KC \& Przasnyski ZH, 2006, Captivate your students' minds: Developing interactive tutorials to support the teaching of spreadsheet modeling skills, INFORMS Transactions on Education, $\mathbf{7}(\mathbf{1})$, pp. 70-87.

[99] Lewis HF \& Sexton TR, 2005, Innovative design for courses with group projects, INFORMS Transactions on Education, 5(3), pp. 33-41.

[100] Liberatore MJ \& Nydick RL, 1999, Breaking the mold: A new approach for teaching the first MBA management science course, Interfaces, 29(4), pp. 99-116.

[101] Liebman JS, 1996, Promote active learning during lectures, ORMS Today, 23(6), p. 8.

[102] LIST B, 2004, Progress report on the INFORMS initiative to market the profession, ORMS Today, 31(1), pp. 22-23.

[103] Long Z, 2009, On case teaching of operations research, First International Workshop on Education Technology and Computer Science, 1, pp. 547-550.

[104] Llewellyn DC, 2006, Tutorial: Pedagogical research - An introductory how-to workshop, Paper presented at the INFORMS Annual Conference, Pittsburgh (PA).

[105] Llewellyn DC, 2007, Pedagogical research, Paper presented at the INFORMS Teaching of Management Science Workshop, Atlanta (GA).

[106] Magel RC, 1998, Using cooperative learning in a large introductory statistics class, Journal of Statistics Education, 6(3), [Online journal], [Cited May $4^{\text {th }}, 2009$ ], Available from http://www . amstat.org/publications/jse/v6n3/magel.html.

[107] Markham IS \& Palocsay SW, 2006, Scenario analysis in spreadsheets with Excel's scenario tool, INFORMS Transactions on Education, 6(2), pp. 23-31.

[108] Markland RE, 1983, Topics in management science, $3^{\text {rd }}$ Edition, John Wiley \& Sons, New York (NY).

[109] McKeachie WJ, Pintrich PR, Lin Y \& Smith DAF, 1986, Teaching and learning in the college classroom: A review of the research literature, National centre for research improve postsecondary teaching and learning, Regents of the University of Michigan, Ann Arbor (MI), available from http://www.eric.ed.gov/ERICDocs/data/ericdocs2sql/content_storage_ 01/0000019b/80/21/88/43.pdf.

[110] McLeish J, 1968, The lecture method, Cambridge Monographs on Teaching Methods, Cambridge Institute of Education, Cambridge (MA).

[111] Metters R, Vargas V \& Weaver S, 2009, MotherLand Air: Using experiential learning to teach revenue management concepts, INFORMS Transactions on Education, $\mathbf{9}(\mathbf{3})$, pp. 124-134.

[112] MorRIS WT, 1967, On the art of modeling, Management Science, 13(12), pp. 707-717.

[113] Monse PM, 1953, Trends in operations research, Journal of the Operations Research Society of America, 1, pp. 159-165.

[114] Müller-Merbach H, 2004, 'Better' campaign doesn't go far enough: Promotion is fine, but the profession needs to build a better OR/MS product with more emphasis on 'operations' and 'management', ORMS Today, 31(1), pp. 20-24.

[115] Munisamy S, 2009, A spreadsheet-based approach for operations research teaching, International Education Studies, 2(3), pp. 82-88. 
[116] NovoA AM \& Cliff J, 1990, Training medical students in operational research in Mozambique, Health Policy and Planning, 5(4), pp. 399-402.

[117] Olsen T, 2008, A critical look at critical thinking, ORMS Today, 35(2), p. 10.

[118] Pachamanova D, 2006, Introducing integer modeling with Excel Solver, INFORMS Transactions on Education, $\mathbf{7}(\mathbf{1})$, pp. 88-98.

[119] Pan African Thoracic Society, 2009, Methods in epidemiologic, clinical E operations research (MECOR): Measuring the burden of disease, [Online], [Cited October 22 ${ }^{\text {nd }}, 2009$ ]. Available from ww. thoracic.org/sections/meetings-and-courses/mecor-courses/resources/ level1-africa-schedule-09.pdf.

[120] Papageorgiou JC, 1996, Are we promoting OR/MS to our future clients? International Journal of Operations and Quantitative Management, 2(3), pp. 231-238.

[121] Pendegraft N, 1997, Lego of my simplex, ORMS Today, 24(1), p. 8.

[122] PIDd M, 1999, Just modeling through: A rough guide to modeling, Interfaces, 29(2), pp. 118-132.

[123] Plane DR, 1994, Spreadsheet power, ORMS Today, 21(6), pp. 32-38.

[124] Plane DR, 1996, Management science: A spreadsheet approach for Windows, Boyd \& Fraser, Danvers (MA).

[125] Plane DR, 1997, How to build spreadsheet models for production and operations management, ORMS Today, 24(6), pp. 50-54.

[126] Powell SG, 1995a, Teaching the art of modeling to MBA students, Interfaces, 25(3), pp. 88-94.

[127] Powell SG, 1995b, Six key modeling heuristics, Interfaces, 25(4), pp. 114-125.

[128] Powell SG, 1997a, From intelligent consumer to active modeler: Two MBA success stories, Interfaces, 27(3), pp. 88-98.

[129] Powell SG, 1997b, Leading the spreadsheet revolution, ORMS Today, 24(6), pp. 8-9.

[130] Powell SG, 1998a, Requiem for the management science course? Interfaces, 28(2), pp. 111-117.

[131] Powell SG, 1998b, The studio approach to teaching the art of modeling, Annals of Operations Research, 82, pp. 29-48.

[132] Powell SG, 2001, Teaching modeling in management science, INFORMS Transactions on Education, 1(2), pp. 62-67.

[133] Powell SG \& BAKeR KR, 2008, Management science: The art of modeling with spreadsheets, John Wiley \& Sons, New York (NY).

[134] RAFFEnsperger JF \& Richard P, 2005, Implementing dynamic programs in spreadsheets, INFORMS Transactions on Education, 5(2), pp. 25-46.

[135] Ragsdale CT, 1995, Spreadsheet modeling and decision analysis: A practical introduction to management science, Course Technology Inc., Boston (MA).

[136] Ragsdale CT, 1998, Spreadsheet modeling and decision analysis, $2^{\text {nd }}$ Edition, South-Western Publishing Company, Cincinnati (OH).

[137] RAGSDALE CT, 2003, A new approach to implementing project networks in spreadsheets, INFORMS Transactions on Education, 3(3), pp. 76-85.

[138] RAU EP, 2000, The adoption of operations research in the United States during World War II, pp. 57-92 in Hughes AC \& Hughes TP (Eds.), Systems, experts and computers, MIT Press, Cambridge (MA).

[139] RAU EP, 2005, Combat science: The emergence of operational research in World War II, Endeavour, 29(4), pp. 156-1671.

[140] Rumsey DJ, 1998, A cooperative teaching approach to introductory statistics, Journal of Statistics Education, 6(1), [Online journal], [Cited June 21 ${ }^{\text {st }}, 2009$ ]. Available from http://www . amstat.org/ publications/jse/v6n1/rumsey.html.

[141] Russell IJ, Hendricson WD \& Herbert RJ, 1984, Effects of lecture information density on medical student achievement, Journal of Medical Education, 59, pp. 881-889.

[142] Savage S, 1997, Weighing the pros and cons of decision technology in spreadsheets, ORMS Today, 24(1), pp. $42-45$.

[143] Schmedders K \& Stephens M, 2001, Time to update teaching cases, ORMS Today, 28(1), p. 14. 
[144] School Spreadsheet Safari, 2001, A timeline of spreadsheet history, [Online], [cited August $1^{\text {st }}$, 2009], Available from http://library.thinkquest.org/J0110054/History.html.

[145] Shumsky RA, 2009, Introductory integrative cases on airline revenue management, INFORMS Transactions on Education, 9(3), pp. 135-157.

[146] TALluRI K, 2009, The customer valuations game as a basis for teaching revenue management, INFORMS Transactions on Education, 9(3), pp. 117-123.

[147] Taras D \& Grossman TA, 2003, Stay or switch: An organizational behavior and management science joint classroom exercise, INFORMS Transactions on Education, 3(2), pp. 42-54.

[148] Teich JE, Wallenius H \& Wallenius J, 2005, The bread/flour/grain trading game: Bidding in and designing auction events, INFORMS Transactions on Education, 5(3), pp. 42-54.

[149] THIRIEZ H, 2001, Improved or education through the use of spreadsheet models, European Journal of Operational Research, 135(3), pp. 461-476.

[150] THIRIEZ H, 2004, Spreadsheet-based professional modelling, INFORMS Transactions on Education, 4(2), pp. 14-27.

[151] Thomas W, 2004, Selling operations research: An historical perspective, ORMS Today, 31(6), pp. 30-36.

[152] TRoxell DS, 2002, Optimization software pitfalls: Raising awareness in the classroom, INFORMS Transactions on Education, 2(2), pp. 40-46.

[153] VAn WASsenhove LN \& Guide VDR, 2008, Managing product returns at Hewlett Packard, Operations Management Education Review, 2, pp. 5-26.

[154] Vazsonyi A, 1993, Where we ought to be going: The potential of spreadsheets, Interfaces, 23(5), pp. 26-39.

[155] Webster R, 1971, The 70's will see the death of OR, Operational Research Quarterly, 22, p. 128.

[156] Winston WL, 1996, The teachers' forum: Management science with spreadsheets for MBAs at Indiana University, Interfaces, 26(2), pp. 105-111.

[157] Winston WL, 2001, Executive education opportunities: Millions of analysts need training in spreadsheet modeling, optimization, Monte Carlo simulation and data analysis, ORMS Today, 28(4), pp. 36-39.

[158] Winston WL, Albright SC \& Broadie M, 1996, Practical management science: Spreadsheet modeling and applications, Duxbury Press, Belmont (CA).

[159] Woolsey RED, 1984, Modeling the modeling process, Interfaces, 14(3), pp. 24-28.

[160] YIN Y, KAKU I \& STECKE K, 2008, The evolution of seru production systems throughout Canon, Operations Management Education Review, 2, pp. 27-40. 